\title{
A PRODUÇÃO SOCIAL DA LINGUAGEM: UMA LEITURA DO TEXTO DE MIKHAIL BAKHTIN (V.N. VOLOCHINOV), MARXISMO E FILOSOFIA DA LINGUAGEM
}

Lauro Frederico Barbosa da SILVEIRA*

\begin{abstract}
RESUMO: Diante do problema de fundamentar criticamente a produção semiótica no interior da formação econômica e social capitalista e mesmo da fase inicial de implantação do socialismo, BAK HTIN, ou seu discípulo VOLOCHINOV, discute as proposições da lingüística de tradição saussuriana e do subjetivismo individualista dos vosslerianos e, evitando o mecanicismo pretensamente marxista, propõe o estabelecimento da instância social e ideológica da formação do discurso. Após elaborar os fundamentos gerais da produção social dos signos, detém-se na análise dos discursos indiretos progressivamente elaborados na literatura burguesa a partir do século XVIII francês.
\end{abstract}

UNITERMOS: Linguagem; signo; tema; enunciação; valoração; entoação; discurso direto; discurso indireto; discurso indireto livre; inf ra-estrutura e super estrutura; ideologia.

\section{O. Introdução à Leitura}

$\mathrm{O}$ texto que se segue constitui uma mera leitura atenta do texto de BAKHTIN. Propunha-se originariamente ser publicado como uma simples resenha mas, devido à extensão que assumiu, julgou-se conveniente que se apresentasse como um artigo. Somente pretende, no entanto, mediatizar a leitura do texto do autor russo sem nada lhe acrescentar senão uma certa organização mais sistemática e a explicitação de alguns conceitos.

Também pretende apresentar a tradução para o português do original russo, louvar o empreendimento dos tradutores e tecer algum comentário sobre a precariedade do trabalho de publicação e impressão realizado no Brasil.

Sendo tal o intento, damos, de imediato, lugar à leitura, iniciando-a com um pequeno resumo da apresentação que Romam JAKOBSON elaborou no momento em que o texto, durante longo tempo exilado pela censura, é trazido a público.
01.01 - As condições da elaboração do texto e sua importância histórica.

A tradução para o português do texto de BAKHTIN** contribui para alimentar no Brasil a discussão sobre os problemas das relações entre linguagem e as condições sociais de sua produção.

$\mathrm{O}$ texto interessante de si mesmo, guarda sobretudo um grande valor histórico. Publicado com a assinatura de V.N. VOLOCHINOV nos anos de 1929-1930 mas da autoria de seu mestre MIKHAIL BAKHTIN, após longo período de ostracismo e esquecimento, ressurge desta vez

\footnotetext{
* Professor Assistente-Doutor do Departamento de Filosofia - Faculdade de Educação, Filosofia, Ciências Sociais e da Documentação - UNESP - 17500 - Marília - SP - Brasil.

** BAKHTIN, MIKHAIL (V.N. VOLOCHINOV) - Marxismo e Filosofia da Linguagem. Problemas fundamentais do Método Sociológico na Ciência da Linguagem, prefácio de Roman Jakobson, apresentação de Marina Yaguello. Tradução brasileira de Michel Lahud e Yara Frateschi Vieira com a colaboração de Lúcia Teixeira Wisnik e Carlos Henrique D. Chagas Cruz, Editora Hucitec, São Paulo, 1979.
} 
no Ocidente Capitalista em 1972 na série Janva Linguarum da Mouton, no mesmo ano sendo publicada a tradução em inglês em Nova Iorque.

Roman JAKOBSON, que oferece em sua introdução estas informações, já salienta a importância da obra no seu caráter pioneiro quando reconhece que ela "... antecipa as atuais explorações realizadas no campo da sociolingüística e, principalmente, consegue preceder as pesquisas semióticas de hoje e fixar-lhes novas tarefas de grande envergadura. A "dialética do signo", e do signo verbal em particular, que é estudada no livro conserva, ou melhor, adquire um grande valor sugestivo à luz dos debates semióticos contemporâneos"'. (p.X)

\subsection{2 - O Debate com as correntes lin- güísticas predominantes}

Debatendo com as duas correntes lingüísticas mais importantes que lhe eram contemporâneas e acessíveis, BAKHTIN esforça-se por caracterizá-las de modo sucinto e preciso a fim de criticá-las e expor dialeticamente uma abordagem objetiva da produção e da função do signo e, em especial, do signo lingüístico. Para as pequenas dimensões do texto - na presente edição em português, o texto de BAKHTIN ocupa 170 páginas de formato médio - o autor consegue alcançar seu intento com clareza e precisão.

Reconhece uma corrente que aborda a questão da linguagem sob o ângulo filosófico e histórico o qual acentua o caráter subjetivo e expressivo dos signos. Esta corrente teria sua origem nos trabalhos de Wilhelm HUMBOLDT e teria se expandido na Alemanha graças sobretudo ao trabalho Karl VOSSLER contando com discípulos tais como Leo SPITZER, LORSK e LERCH. Na tradição lingüística russa, POTEBNIA e seus discípulos da escola de Kharkov é quem desenvolve este tipo de abordagem, devendo-se aproximar da mesma, na Itália e posteriormente em toda a Europa, a concepção estética e lingüística de Benedetto CROCE. O caráter psicológico do ato criativo da expressão determina o enfoque que por esta corrente é dado ao signo lingüístico.

A corrente oposta exalta o caráter objetivo e o histórico que deve assumir o objeto imediato da lingüística. Colocando-se no caudal da concepção positivista da ciência, restringe-se a abordar o fenômeno lingüístico como um "fato", isolando-o, enquanto objeto de investigação, das variantes concretas de natureza individual ou de qualquer marca de um processo evolutivo de formação de natureza histórica. Ferdinand de SAUSSURE é reconhecidamente a figura de proa desta corrente e sua influência é decisiva não só entre os lingüístas de expressão francesa na qual destaca-se a figura de Charles BALLY, como na própria lingüística russa com R.SCHORR, WINOGRADOFF e as escolas de FORTUNATOFF e de KASAN. A poética russa, contemporânea aos trabalhos de BAKHTIN, sofre nítida influência desta concepção do signo lingüístico. Opondo-se à consideração psicologista do fenômeno da comunicação, estabelece com SAUSSURE a distinção entre "langue" e "parole" no interior do fenômeno da linguagem e concentra sua atenção especialmente sobre a "langue" pois esta independe das individualidades dos sujeitos falantes e constitui-se num sistema normativo de natureza formal.

Distinguindo lapidarmente o sistema normativo da formação histórica dos elementos deste sistema, reconhece duas lingüísticas: - a sincrônica e a diacrônica , e escolhe a primeira como o objeto adequado da investigação científica.

Em sua crítica a cada uma das correntes, BAKHTIN procura detectar seu erro primeiro ou nuclear - proton pseudos (p. 73, 98, 107 s). A tendência do objetivismo abstrato de que SAUSSURE é o mais notório representante, peca na base por separar "langue", e "parole", 
opondo radicalmente, através delas, a instituição social ao ato exclusivamente individual (p.73). Peca igualmente quando atribui à diacronia e à história uma irracionalidade que a afasta definitivamente do domínio da ciência (p. 73). A tendência que aborda o fenômeno da linguagem do ponto de vista subjetivista e idealista tem o mérito de "sustentar que as enunciações isoladas constituem a substância real da língua e que a elas está reservada a função criativa na língua'" (p. 107) mas deixa de compreender adequadamente o problema da produção do signo ao nível comunicativo e expressivo uma vez que reduz à subjetividade individual o ato da fala atribuindo à enunciação, mesmo do signo interior, um caráter acidental, limitativo e deformador da expressividade subjetiva (p.98).

Tomando posições opostas, ambas as correntes não satisfazem às exigências da natureza do fenômeno lingüístico. Tendem a estabelecer cortes demasiadamente abruptos para determinar as feições do objeto lingüístico, quer separando a "langue' da "parole"' (pg. 73), quer estabelecendo uma estranheza essencial entre o conteúdo interior e a objetivação exterior, chegando às exacerbações românticas de TCHUTCHEV ao dizer que "O pensamento expresso pela palavra é uma mentira" ou de FET ao exclamar "Oh, se pelo menos alguém pudesse exprimir a alma sem palavras"'. (p. 97 n. ${ }^{\circ}$ 1) Desconhecem o caráter social da produção do signo determinante do fenômeno semiótico, e em particular do fenômeno lingüístico, não só na instância da exteriorização sob a forma de enunciados mas da própria formação ao nível da consciência. (p. 174)

Somente por uma abordagem que considere a própria formação da consciência no âmbito das relações sociais e que determine suas relações com a esfera ideológica e suas manifestações, é possível definir o estatuto do signo, e em especial do signo lingüístico, sem cair nas abstra- ções do objetivismo lingüístico ou do subjetivismo idealista.

\subsection{1. - O Marxismo e o fenômeno da linguagem}

O estabelecimento correto do problema é o que pretende o autor realizar, pois em seu tempo - como mesmo ainda hoje - a questão das formas ideológicas da representação, sobretudo quando pretende equacionar os fundamentos criticofilosóficos da linguagem sob a luz da análise marxista, ainda não tinha recebido um tratamento adequado. Nos parágrafos iniciais do prólogo do livro, o autor demonstra plena consciência desta situação e justifica, diante da extrema complexidade do empreendimento, os limites de sua exposição:. . . "Portanto, a problemática de nosso trabalho, que desbrava, de certa forma, um terreno ainda virgem, só pode, evidentemente, situar-se num nível bastante modesto. Não se trata de uma análise marxista sistemática e definitiva dos problemas básicos da filosofia da linguagem. Tal análise só poderia resultar de um trabalho coletivo de grande fôlego. De nossa parte, tivemos que nos restringir à simples tarefa de esboçar as orientações de base que uma reflexão aprofundada sobre a linguagem deveria seguir e os procedimentos metodológicos a partir dos quais esta reflexão deve estabelecer-se para abordar os problemas concretos da lingüística”. (p. 11)

Para realizar esta tarefa tem se confrontar no próprio seio dos trabalhos que desenvolvem o pensamento marxista, com as tendências reducionistas do fenômeno lingüístico à esfera das “. . . particularidades da consciência e do psiquismo"' ( $p$. 11), e com o freqüente emprego de “. . . categorias do tipo mecanicista', em domínios que, por ausência de estudos mais desenvolvidos realizados por Marx e Engels, encontram-se. . ." no estádio do materialismo mecanicista pré-dialético'. (p. 11) 
Mas é impossível negar a importância dos problemas de filosofia da linguagem tanto no interior da concepção marxista do mundo quanto na produção filosófica contemporânea. As múltiplas implicações que o problema estabelece no interior do marxismo exige uma análise cuidadosa e a atualidade candente do tratamento do fenômeno na sociedade burguesa, cuja filosofia... "está se desenvolvendo sob o signo da palavra"' (p. 12), requer uma atitude crítica que elucide com cuidado os diversos posicionamentos e contraponha aos possíveis limites e deformações do equacionamento do problema, a real conjunção dos fatores nele implicados.

Diante desta desafiante tarefa, BAKHTIN propõe uma abordagem em três estágios sucessivos cuja seqüência obedece a uma particularização progressiva. Propõe uma divisão da obra em doze capítulos agrupados em três partes, cabendo à primeira. . " "indicar o lugar dos problemas da filosofia da linguagem dentro do conjunto da visão marxista do mundo"' (p. 13); à segunda, desenvolver. . " "O problema da natureza real dos fenômenos lingüísticos", discutindo as questões "da evolução da língua, da interação verbal, da compreensão e o problema da significação"' (p. 13); e à terceira, o estudo concreto de uma questão de linguagem que, segundo o autor, só recebe um tratamento adequado quando abordado por uma teoria sintática fundamentada numa filosofia que equacione a produção social dos signos lingüísticos. Trata-se da análise das refrações diversas que assume, na produção literária, o discurso de outrem e, em especial, do discurso indireto livre.

02.02. - Linguagem, consciência e ideologia

As relações entre linguagem, consciência e ideologia constituem o objeto da primeira parte.
Nela, o autor critica as posições que atribuem a precedência da consciência relativamente a linguagem e, conseqüentemente, do individual subjetivo face ao social, salientando a filosofia de Wilhelm DILTHEY por fundar na psicologia a classe das ciências do espírito, as quais privam o mundo material de qualquer sentido e de toda significação, em benefício de um "espírito" fora do tempo e do espaço (p. 35). Recusa igualmente a abordagem funcionalista do fenômeno psíquico que separa drasticamente o conteúdo da atividade mental da forma de seu procedimento, atribuindo o conteúdo ao contexto social (ideologia) e retendo somente a forma - o como em oposição ao o que - como objeto da análise psicológica. (p.40) Reconhece porém, na primeira concepção, o mérito de não reificar o fenômeno psíquico na medida mesma em que o toma como essencialmente relacional, com um fenômeno de significação. A outra concepção também não é desprovida de verdade, sobretudo quando atribui ao ideológico uma precedência sobre o psíquico.

Trata-se, contudo, de posições atravessadas por radical parcialidade a qual deforma, de um ou outro modo, o estatuto do psíquico, do semiótico e do ideológico.

$\mathrm{Na}$ constante alternância entre o psicologismo redutor de toda a atividade sígnica à expressão da individualidade subjetiva e do anti-psicologismo que subtrai qualquer atividade interior da consciência, denuncia BAKHTIN o conflito no qual se debate o pensamento burguês e julga poder afirmar que ". . . a filosofia burguesa até o momento não resolveu o problema das relações entre psicologia e ideologia. (p. 43)

Somente uma abordagem crítica que dialetise ambas as posições colocará corretamente a questão do signo e da consciência, da psicologia e da ideologia. 
Partindo da proposição que o signo é condição necessária para a existência da ideologia, BAKHTIN afirma, em concordância com o pensamento de MARX, que a consciência só pode surgir e se afirmar como realidade mediante a encarnação material em signos. (p. 19) Como o signo se instaura num processo de interação social, a consciência é um fato sócioideológico.

A consciência adquire forma e existência nos signos criados por um grupo organizado no curso de suas relações sociais. Os signos são o alimento da consciência individual, a matéria de seu desenvolvimento, e nela vê refletidas sua lógica e suas leis. A lógica da consciência é a lógica da comunicação ideológica, da interação semiótica de um grupo social. De modo que, se privarem a consciência de seu conteúdo semiótico e ideológico, dela não sobra nada. (cf. p. 21)

Devido a sua pureza e neutralidade, ou seja, devido ao fato de constituir-se somente como signo, não possuindo outro uso senão o semiótico e por poder preencher qualquer espécie de função ideológica e mesmo por somente exigir o próprio organismo humano como meio de sua produção, a palavra é assumida pelo autor como a classe privilegiada dos signos para a análise das relações entre consciência e ideologia, quer ao nível interior à própria consciência - a constituição do discurso interior - quer ao nível de suas manifestações exteriores:... "como instrumento da consciência, a palavra funciona como elemento especial que acompanha toda criação ideológica, seja ela qual for'.' (p. 23) 'Presente em todos os estágios e em todas as dimensões da formação da consciência e sendo profundamente maleável em sua formação, constitui-se o signo lingüístico no indicador mais adequado das configurações assumidas pela consciência em seu processo de representar: "toda refração ideológica do ser em processo de formação é acom- panhada de uma refração verbal"' (p. 24). Deste modo pode BAKHTIN concluir no final do $1 .^{\circ}$ capítulo, que a "palavra é o objeto fundamental do estudo das ideologias" e é da análise filosófica de seu estatuto e de seu processo de formação, que o marxismo poderá elaborar uma crítica da ideologia.

A tradição marxista, porém, não permite que a análise da linguagem e, por conseqüência, das relações entre consciência e ideologia se faça sem que se esclareçam as condições de determinação da ideologia. A tendência a um simplismo exagerado ronda constantemente a abordagem das formas ideológicas, desfigurando-as. A determinação das formas de representação da consciência ou das superestruturas tem com freqüência assumido a forma de uma causalidade de tipo mecanicista. Para bem equacionar o problema desta determinação, torna-se necessário, no dizer do autor, “...seguir as diversas esferas de influência recíproca e todas as transformações..." (p. 25) das relações materiais da produção e dos elementos do conjunto único e indivisível que constitui a esfera ideológica como uma totalidade. É no estudo do material verbal, - sendo a palavra um indicador sensível das relações sociais, capaz de representar as mais inúmeras fases transitórias das mudanças sociais antes que, pelo resultado de uma acumulação quantitativa, surja uma forma ideológica nova e acabada - , que a forma desta determinação poderá ser explicitada.

No segundo capítulo, assume BAKHTIN o conceito de Psicologia do corpo social, elaborado anteriormente por PLEKHÂNOV, como “o elo de ligação entre a estrutura sócio-política e a ideologia no sentido estrito (ciência, arte, etc', (p. 27) e que, sempre se materializando sob forma de interação semiótica - especialmente verbal - constitui-se no meio ambiente inicial dos atos da fala. Tal conceito manifesta-se nos diversos aspec- 
tos da "enunciação", sob a forma de diferentes modos de discurso (internos e externos) sensíveis as mudanças sociais às quais se vinculam (p. 28)

Como processo ativo de representação, deve ser estudado não só em seu conteúdo - nos temas atualizados num certo momento - , mas nos tipos e formas concretas que plasmam esses temas.

Estas formas, através de sua tipologia, devem ser estudadas pelo marxismo, pois a elas correspondem como determinantes, as relações de produção e a estrutura sócio-política do momento histórico em que surgem. (p. 29)

Só pelo estudo da mútua influência do signo e do ser, da complexa esfera da representação e da esfera não menos complexa das relações de produção e da estrutura sócio-política de que a consciência é consciência, pode-se, segundo o autor, clarificar a determinação causal do signo pelo ser. Determinação de modo algum transparente ao nível da representação, mas refratada dialeticamente no signo.

O signo retrata o ser. Traz as marcas do horizonte social de sua época e dos grupos sociais determinados que o produzem. Mas sempre atravessado pelas valorações sociais atribuídas aos objetos, sempre produzirá, na medida mesma em que se constitui em elemento de comunicação entre os grupos, refrações do ser que significa. (p. 29s).

Como na sociedade de classe há contradições que a atravessam estruturamente, as valorações sociais atribuídas aos objetos reproduzem estas contradições. Como porém a mesma linguagem atua como meio de comunicação entre os diversos grupos sociais, BAKHTIN (p. 32) salienta a não coextensividade entre classe social e comunidade semiótica, decorrendo daí que “...em todo signo ideológico confrontam-se índices de valor contraditórios". O signo é a arena onde se desenvolve a luta de classes. Deste confronto decorre o processo evolutivo do signo apesar da resistência da classe dominante que tenta preservar nos signos o valor da verdade de ontem como sendo válido hoje em dia; valoração que ela impôs quando se sobrepôs à classe que antes a dominava e que agora tornou indefinidamente estável.

Descaracterizando a dinâmica do processo de significação e valoração, numa tentativa inútil de resistir às mudanças sociais, salienta-se o caráter refratário do signo nos limites da ideologia dominante.

A crise dialética do signo, disfarçada em muitos momentos da vida social, revela-se plenamente nos períodos revolucionários (p. 33).

A fim de insistir no caráter fundamentalmente social da produção do signo e, por conseqüência, da consciência, é que BAKHTIN, no $3 .^{\circ}$ capítulo, estabelece a já mencionada díscussão com as correntes de pensamento que, ou atribuem à consciência individual subjetiva prioridade e antecedência face ao signo, ou desqualificam qualquer instância instauradora de significação à consciência.

Os fundamentos de uma psicologia objetiva não podem ser buscados nas áreas da fisiologia ou da biologia onde o indivíduo é visto como um mero organismo mas na sociologia, onde a formação da consciência e de sua expressão é considerada como o resultado das interações sociais.

Não há psiquismo sem material semiótico. A atividade psíquica implica na expressão semiótica entre o organismo e o meio exterior, e, por conseguinte, deve ser analisada como um signo. (p. 34s)

A significação, contrariamente à posição de DILTHEY, é vista por BAKHTIN, não como uma pura expressão do "espírito", mas como função do signo e não pode ser representada como independente dele. (p. 35) 
Opondo-se, portanto, a uma visão dicotômica que opõe psiquismo interior e relações sociais - de natureza ideológica -, o autor pode afirmar que "a passagem da atividade mental interior ocorre no quadro de um mesmo domínio qualitativo, e se apresenta como uma simples mudança quantitativa"' (p. 38) E pode concluir que a palavra é o fundamento da vida interior.

Esta crítica, se é dirigida as posições que defendem a psicologia como fundamento das "ciências do espírito", passa a se opor também à psicologia funcionalista, embora esta recuse ao espírito qualquer estatuto privilegiado ou mesmo qualquer consciência ao nível do psiquismo individual. Aproximando o psiquismo do modo de funcionar de qualquer organismo que opera sobre um conteúdo que lhe é estranho, reafirma por um encaminhamento oposto ao idealismo diltheyano a separação igualmente radical entre $o$ psíquico e o ideológico, a esfera mental e a esfera social. Opõe, - ao nível ideológico - , se bem que sem a necessária precisão conceitual, ao psiquismo individual (orgânico), algo como uma "consciência global" caudatária da "consciência transcedental' kantiana. (p. 40ss)

Propondo a superação dessas posi'ções antagônicas através da crítica da falha comum a ambas: a separação entre individual e social ou ideológico como instâncias mutuamente irredutíveis, BAKHTIN vai rever o próprio estatuto do individual e, por conseqüência, os da interioridade subjetiva e da exteriorização ideológica. Assumindo a existência do discurso interior e do discurso exterior, não vai opô-los como domínios antagônicos e irreconciliáveis, mas vai neles reconhecer duas instâncias de um processo único as quais mantêm entre si uma interação dialética.

O social não se opõe ao individual enquanto pessoa mas ao natural, ou seja, ao individual enquanto organismo biolo- gicamente considerado. O processo da individualização ao nível da consciência constitui um fenômeno sócio-ideológico determinado historicamente. (p. 44)

$\mathrm{O}$ signo interior distingue-se do signo exterior não pela sua natureza mas pelo seu destinatário. Trata-se de um movimento dirigido ao próprio organismo e determina-se no contexto de sua individualidade. Esta determinação, porém, se faz pela totalidade das condições vitais e sociais que constituem esta individualidade e só é captado através dos signos ideológicos, os quais se esclarecem por oposição a outros signos. A interioridade nằo é inefável, sua explicitação se faz necessária para sua plena constituição e tende, por conseqüência, a assumir uma forma semiótica, objeto de observação exterior, a qual implica uma situação social determinada. (p. 45-48)

Se, porém, o discurso interior se realiza no interior do domínio semiótico, nem por isso é analisável adequadamente pelas categorias lingüísticas tradicionais de caráter estritamente analíticoelemental. Suas formas mínimas são monólogos completos e réplicas de um diálogo sem que laços gramaticais unam essas réplicas. Suas ligações seguem leis de convergência apreciativa de natureza emocional e leis próprias de concentrações de diálogos em estrita dependência das condições históricas da situação social e do curso programático da existência. (p. 49s)

É, conseqüentemente, no campo do signo reconhecido como unidade inviolável de uma forma e de um conteúdo socialmente determináveis, ou seja, ao nível de seu tema, que as fronteiras entre o psíquico e o ideológico poderão ser delimitadas.

O signo ideológico tem vida na medida em que ele se realiza no psiquismo e, reciprocamente, a realidade psíquica vive sustentada pelo suporte ideológico. (p. 50). 
Esta mútua implicação realiza-se, porém, de uma maneira estritamente dialética: pela obliteração e destruição dos pólos para reciprocamente se efetivarem.

Assim, terminando a argumentação do $3 .^{\circ}$ capítulo e com ele completando a apresentação do modo como o pensamento dialético materialista deve instaurar a questão da produção da linguagem, BAKHTIN considera que o signo interior deve ser experimentado subjetivamente para se tornar signo ideológico; devendo, por sua vez, o signo ideológico integrar-se no domínio dos signos interiores para permanecer vivo, evitando assumir' '... o estatuto honorífico de uma incompreensível relíquia de museu', signo morto, objeto da filologia tradicional. (p. 51)

\subsection{3. - Dialética e Lingüística}

Nos quatro capítulos da segunda parte, pretende BAKHTIN determinar a natureza do objeto da ciência da linguagem e o tipo de abordagem que deve esta ciência realizar para apreendê-lo adequadamente.

É no contexto da discussão com a concepção "objetivista abstrata" e "subjetivista idealista"' da linguagem e da própria ciência lingüística, que a proposta que parece correta a BAKHTIN, vai se elaborar. O núcleo da crítica, como já se mencionou, é o estabelecimento em ambas as tendências de uma dicotomia radical entre o indivíduo e o meio institucional onde se encontra inserido; dicotomia que, desconsiderando ora uma instância, ora a outra, reduz o fenômeno da linguagem a uma mera expressão da subjetividade individual ou elege a língua, enquanto instituição social, como único objeto passível de um estudo científico e sistemático.

A tese defendida por BAKHTIN é a de que a linguagem somente pode ser analisada como uma produção concreta dos atos da fala, atos estes produzidos por in- divíduos historicamente determinados e em que o fator ideológico e o fator expressivo não se contrapõem como instâncias antagônicas, mas como dimensões que interagem constantemente na produção do fenômeno integral semiótico.

A questão que se coloca é de esclarecer as relações precisas entre estas instâncias, definindo os elementos que compõem o fenômeno. Exige uma determinação clara do elemento lingüístico em que deve se basear a análise; o modo de sua formação; suas dimensões significantes para o estudo; o grau de estruturação que apresenta nas diversas relações do sujeito com seu auditório e o grau de significância que assume na compreensão dos fatores sociais que determinam sua produção.

Dedicando o capítulo quarto do livro, - o primeiro que compoẽ a segunda parte - à exposição das duas correntes que dividem a abordagem do fenômeno da linguagem, reserva BAKHTIN os três outros capítulos à crítica de cada uma delas e à exposição da abordagem que lhe parece mais adequada. O capítulo quinto dedica-se a refutar as propostas do "objetivismo abstrato"; o seguinte, aquelas formuladas pelo "subjetivismo idealista" e o último a definir positivamente a natureza e o estatuto da linguagem, tendo por unidade a enunciação.

\subsubsection{1. - Crítica ao objetivismo abstrato}

Do “objetivismo abstrato" e das teorias lingüísticas dele caudatárias, a crítica fundamental é o fato de tomar a língua como um sistema normativo sincrônico e nela encontrar o objeto da ciência da linguagem.

Seu caráter normativo para a comunidade dos falantes é absolutamente falso.

O sistema lingüístico é produto de uma reflexão abstrata sobre a língua, não procede do locutor nativo e não serve aos 
propósitos imediatos da produção (p. 78). Também o interlocutor dele não se serve para a descodificação das mensagens. $\mathrm{Na}$ descodificação, diz o autor, o essencial não consiste em reconhecer a forma utilizada, mas compreendê-la num contexto concreto preciso; o essencial é compreender sua significação numa enunciação particular. (p. 79)

Distinguindo o sinal do signo, e atribuindo aos sinais as características da classe dos estímulos mais ou menos complexos que atingem a sensibilidade, só face a eles, reconhece a atitude do sujeito de meramente os identificar e, somente a eles, a imobilidade, diríamos, de vinculação aos fatos brutos. Os signos são objetos de compreensão e não de mera identificação, e são descodificados pela mobilidade que os caracteriza no interior do contexto em que concretamente se inserem.

Somente uma língua estrangeira, pouco dominada pelo descodificador, apresenta-se-lhe como um objeto a ser identificado e reconhecido... "A assimilação ideal de uma língua dá-se quando o sinal é completamente absorvido pelo signo e o reconhecimento pela compreensão', (p. 80)

No processo de comunicação entre membros de uma comunidade lingüística, não se percebe o caráter coercitivo das formas lingüísticas (p. 80). Em condições normais, o critério da correção lingüística cede lugar ao critério permanente ideológico de que toda a palavra, na forma da enunciação, está inseparavelmente carregada. Importa-nos menos a correção da enunciação do que seu valor de verdade ou de mentira, seu caráter poético, vulgar, etc. A eleição da língua como situação normativa como objeto da lingüística, falseia radicalmente sua pretensão explicativa do fenômeno da comunicação verbal e não justifica o método abstrativo que estas teorias pretendem adotar.
Não se limitando, porém, a denunciar a inadequação desta corrente lingüística, inadequação que volta a ser apontada no final do capítulo quando insiste que o sistema de formas não pode servir de base para a compreensão e explicação dos fatos lingüísticos enquanto fatos vivos e em evolução, mas que ele nos distancia da validade evolutiva e viva da língua, de suas funções sociais, apesar das freqüentes pretensões a uma significação sociológica que estas abordagens pretendem apresentar (p.94), BAKHTIN propõe-se penetrar nas razões históricas e ideológicas que explicam esta visualização do problema.

Aproximando-se de Nicolas MARR, do qual integra em sua exposição trechos das "As Etapas da Teoria Jafética(1926) aponta, o autor, a antiga origem desta concepção de língua presente nas propostas contemporâneas. A lingüística é filha da filologia que se preocupava em decifrar monumentos antigos separados do contexto concreto de sua produção. Nos trabalhos filológicos, encontra os ancestrais de seu método de trabalho e das categorias que utiliza. $\mathrm{O}$ texto se lhe apresenta como uma enunciação monológica, cuja compreensão assume um caráter eminentemente passivo de identificação, reconhecimento, e decifração e "a língua se apresenta como estrangeira para o lingüısta”. (p. 83s)

E mais ainda: a lingüística e sua ancestral, a filologia, e com ela a própria Filosofia e Teologia, trazem a marca da reprodução de uma estrutura social deposta. A lingüística é marcada não só pelo espírito da pesquisa de textos antigos, estrangeiros, mas pelo ensino. Da leitura de textos míticos, da pesquisa do "logos" e da interpretação das Escrituras, este filão do estudo da linguagem está reservado aos sacerdotes, às autoridades do saber. Penetrar no "mistério"' do texto e ensinar sua significação, é uma função de imposição de um poder. O caráter normativo da 
língua traz consigo a marca do exercício deste poder. Para o exercício desta dupla função: - uma heurística, a outra pedagógica - instauram-se as categorias que até hoje constituem o arcabouço da lingüística e definem suas três grandes divisões: a fonética, a gramática e o léxico, todas elas analíticas e fraccionantes da enunciação. (p. 84s)

Pela exaltação do texto críptico, da língua estrangeira portadora de santidade, de poder, força e verdade, estabeleceu-se a desqualificação da língua nativa destituída de "mistério" e poderíamos deduzir, da comunidade que só a ela tem acesso.

Desvinculada da história de sua formação e da consciência a ela ligada, a língua torna-se mera norma abstrata na qual só se penetra passiva e obedientemente. (p. 86-88)

Na base do objetivismo abstrato está a premissa de uma visão racionalista e mecanicista, inadequada para a concepção concreta da língua como um fenômeno permanentemente histórico. (p. 94-95)

\subsubsection{2 - Crítica ao "Subjetivismo idealista",}

Se a corrente "subjetivista idealista" tem o mérito de ter nascido no interior do pensamento romântico-nativista e assim voltar seu interesse para a lingua materna, viva procurando compreender o ato vivo da expressão dos individuos, traz a falha, já apontada, de centralizar com exclusividade na interioridade do sujeito a origem da expressão e da consciência, tomando as expressões exteriores como simples marcas deformadas e degradadas desta subjetividade. (p. 96-98)

A esta visão, contrapõe BAKHTIN uma concepção essencialmente social e dialógica do fenômeno lingüístico e da própria formação da subjetividade.

"Não é a atividade mental que organiza a expressão, afirma o autor, mas, ao contrário, é a expressão que organiza a atividade mental, que a modela e determina sua orientação'’. (p. 98)

Todos os aspectos da expressãoenunciação serão determinados pela situação social mais imediata do ato da fala.

Toda a palavra é dialógica e supõe um certo horizonte social que determina a criação ideológica do grupo social e da época a que pertence. Este é o horizonte contemporâneo da produção literária, científica, moral e jurídica.

O mundo interior tem um auditório social em cuja atmosfera se contraem as deduções interiores, as motivações, as apreciações, etc.

O mundo interior, - a subjetividade - é plasmado social e ideologicamente. O interlocutor, e por conseqüência, o ato da fala, não podem ultrapassar as fronteiras de uma classe e de uma época bem definidas.

A materialização da palavra como signo é determinada pelas relações sociais concretas em que se ef etua. (p. 99)

A estrutura da atividade mental é tão social como sua objetivação exterior. O grau de consciência, clareza e acabamento formal da atividade mental é diretamente proporcional ao grau de orientação social em que esta se situa. (p. 100)

Fora de sua objetivação social, de sua realização material determinada pelo gesto, pela palavra, pelo grito - a consciência é uma mera ficção. Mas, com a objetivação social, a consciência tornase uma força real, capaz de exercer, em retorno, uma ação eficaz sobre as bases econômicas da vida social. Materializa-se em organizações sociais definidas e impõemse por uma expressão ideológica sólida ao nível da ciência, das artes, do direito. Mesmo não tendo alcançado tal nível de organização, a consciência é originariamente um fato social; caso contrário, este salto ao social nunca se realizaria ( $p$. 104) 
É numa referência constante à ideologia do cotidiano, nível menos sïstematizado da esfera ideológica, que a ciência, a arte, a religião recebem sua avaliação crítica e significação social. A avaliação crítica, que é, segundo BAKHTIN, a única razão de ser de toda produção ideológica, opera-se na lógica da ideologia do cotidiano, colocando toda obra, por mais sistematizada que seja, numa situação social determinada, ou seja, no contexto dos indivíduos receptores nos diversos momentos concretos da história. (p. 105)

Quanto mais profundamente interage com as relações sociais, mais se desenvolve e se aproxima a produção da consciência. O aperfeiçoamento da "individualidade criadora" se fará pela interação mais intensa dos indivíduos com seu auditório social. Menos sua produção dependerá de fatores meramente biográficos e, "a fortiori", biológicos. Para a interpretação desta produção, terá total primazia o método sociológico, não o que se baseia em resultados das análises estatísticas, mas o que mais aprofunde e elucide a complexas relações sociais. (p. 107)

A enunciação, sua elaboração estilística e a própria cadeia verbal, às quais se reduzem a realidade da língua, são fenômenos estritamente sociais e constituem elos de uma evolução histórica. Forma e conteúdo são indivisíveis e este último não pode ser deduzido das condições do psiquismo individual. A forma essencial da língua é dialógica e só pode ser esclarecida sociologicamente. Se Leo SPTIZER e Otto DIETRICH tiveram o mérito de criticar a condição monológica em que era inserida a enunciação nos estudos lingüísticos, falharam por reduzir o diálogo a parâmetros da individualidade subjetiva em vez de tê-lo estudado sociologicamente. (p. 107s)

A língua vive e evolui historicamente na comunicação verbal concreta em constante entrelaçamento com outros tipos de enunciação e cresce com eles sobre o terre- no comum da situação de produção. Não será através da identificação. da língua com o sistema lingüístico abstrato das formas da língua, nem ao percebê-la como emanação comprometida do psiquismo individual dos falantes, que ela poderá ser adequadamente abordada. (p . 110)

$\mathrm{O}$ componente da língua que deve se constituir em objeto a partir do qual ela deve ser estudada, é a enunciação tomada como um todo. Ela constitui a unidade real da cadeia verbal e não pode ser destituída do seu caráter fundamentalmente histórico. Sua realização se dá no curso da comunicação verbal, sua totalidade sendo determinada pelos limites que se configuram pelos pontos de contacto com o contexto em que se insere (p. 110).

Reconhecendo este estatuto da enunciação, pode BAKHTIN recolocar a questão das relações entre o processo interior e o processo exterior da fala, entre a atividade mental e comunicação social. O processo da fala, é um processo único que compreende uma dimensão interior e uma exterior. Trata-se de um processo ininterrupto, sem começo nem fim, em que a enunciação realizada exteriormente constitui-se, no dizer metafórico do autor, numa ilha no oceano sem limites do discurso interior e em profunda interrelação com ele. As dimensões desta ilha, ou seja, da enunciação enquanto ato de esteriorização, são estabelecidas pelas exigências sociais do ambiente ideológico imediato.

As condições sociais em que se inscreve a enunciação determinam a forma concreta que assumirá (p. 111). Deste modo pode concluir BAKHTIN que, "uma análise fecunda das formas do conjunto de enunciações como unidades reais da cadeia verbal só é possível de uma perspectiva que encare a enunciação individual como um fenômeno puramente sociológico"'. (p. 112)

Cabe, portanto, à filosofia marxista da linguagem, para não falsear ideologi- 
SILVEIRA, L.F.B. da. - A produção social da linguagem: uma leitura do texto de Mikhail Bakhtin (V.N. Volochinov), marxismo e filosofia da linguagem. Trans/Form/Ação, São Paulo, 4:15-39, 1981.

camente o fenômeno, . . . "colocar como base de sua doutrina, a enunciação como realidade da linguagem e como estrutura socio-ideológica"'. (p. 112)

Esta é a tarefa que BAKHTIN se proporá realizar no último capítulo desta parte e que tentará verificar, na seguinte, em um caso preciso cujo tratamento, sobretudo pela corrente idealista e subjetivista da linguagem que por ele muito se interessou, caía em impasses insolúveis.

\subsubsection{Esboço de uma filosofia mar- xista da linguagem}

Tomada a enunciação como a unidade real que deve ser analisada pela ciência da linguagem e que deve ser constituída por uma filosofia de linguagem, BAKHTIN reconhece-a como constituída de dois elementos: o tema e a significação.

Toda enunciação completa é dotada de um sentido único e definido, uma significação unitária. Este sentido é o tema da enunciação o qual integra como uma unidade, conforme já foi mencionado, a forma e o conteúdo da enunciação.

Se a enunciação é tomada como um todo concreto e singular, na medida em que se constitui no ato da fala, o tema deve ser único, individual e não reiterável; é a expressão de uma situação histórica concreta na qual tem origem e se ef etua a enunciação. É determinado pelas formas lingüísticas ef etivadas no ato de sua emissão assim como pelos elementos não verbais que integram a situação da emissão. (p. 114)

A enunciação não se reduz, portanto, às sentenças analisadas pela lingüística tradicional. Não é um caso de uma classe abstrata de construções possíveis dentro da língua, como também não constitui um mero recurso instrumental utilizado pela subjetividade para expressar uma produção inefável que, só no interior do espírito, seria genuína. É um ato concreto e dia- lógico entre sujeitos que, se comunicando, constroem sua própria consciência.

Se é um ato dotado de sentido, a um tempo expressivo e comunicacional, a enunciação supõe, no interior do tema como um componente necessário para a sua constituição, elementos reiteráveis e idênticos todas as vezes que são repetidos; elementos convencionais que permitem a inversão efetiva entre os agentes da fala. No interior da concretude singular do tema, estão presentes os elementos de significação.

Devido a seu estatuto abstrato e convencional, somente a significação é passível, segundo o autor, de análise pela decomposição da enunciação nos elementos lingüísticos que a compõem. (p. 115)

O tema, resumindo o texto de BAKHTIN, é um sistema dinâmico e complexo que tende a adaptar-se às condições de um todo, no interior de um processo evolutivo. É "uma reação da consciência em devir ao ser devir'”. (p. 115)

A significação, por sua vez, é o aparato técnico utilizado para a realização do tema.

Só há significação como elemento de um tema; mas o tema só tem sentido, apoiado na estabilidade da significação.

O tema é a ef etivação de significação, sendo esta última um potencial socialmente disponível, somente ef etivado no interior de um tema concreto.

O tema precede a significação pela sua natureza. Se houvesse uma palavra insignificante ela seria um tema puro. Mas a complexidade das relações sociais exige a presença de várias palavras. Neste momento, tema e significação se distinguem, se bem que sempre o tema implique, devido à concretude da situação de sua atualização, uma pluralidade de significações. (p. 116s)

Devido ao seu caráter singular e, diríamos, plasmador da consciência pela 
efetiva interação que estabelece entre os agentes da fala, o tema não é apreendido por um processo de mero reconhecimento e identificação. Supõe uma forma ativa de compreensão e tem sempre em germe uma resposta. Só esta resposta compreensiva é capaz de apreender o tema. (p. 117)

Situações familiares fazem com que a intimidade do contexto em que se situa o ato enunciativo permita que enunciações dispensem o uso de significações explícitas. O tema é aí realizado através da entoação expressiva, sem o auxílio da significação e da articulação gramatical. O tema implica antes de tudo uma apreciação da parte do sujeito, apreciação esta que, em muitos casos, é desprezada pelo lingüista tradicional, considerando-a decorrente de elementos para-lingüísticos. (p. 120)

Para BAKHTIN a dimensão apreciativa deve ser integrada como preocupação central e indissociável do estudo da linguagem, devendo ser procurados seus índices na abordagem da enunciação.

A significação objetiva forma-se graças à apreciação, pois é ela que indica que uma determinada significação entrou no horizonte dos interlocutores. A língua como fenômeno histórico, como processo evolutivo, depende essencialmente da apreciação social ef etivada nas enunciações. A ela se deve o papel criativo das mudanças de significação. Toda mudança de significação é uma reavaliação do sentido e a efetivação de um novo tema. Trata-se do deslocamento de uma palavra determinada de um contexto apreciativo para um outro. (p. 121)

As mudanças relevantes ao nível da significação das enunciações constituem fenômenos de profunda inserção nas situações sociais e somente como fenômenos sociais podem ser investigadas. As avaliações realizadas ao nível dos grupos sociais que efetuam tais mudanças, respeitadas a natureza e a dinâmica própria dos fenômenos locucionais e comunicativos, devem ser objeto de uma ciência que se baseie numa crítica dialética da produção, respeitando a totalidade do fenômeno.

O sentido da totalidade de tudo que assume importância aos olhos de um determinado grupo é, na proposta de BAKHTIN, inteiramente determinado pela expansão da infra-estrutura econômica.

Atento, como a terceira parte de Marxismo e Filosofia da linguagem vai comprovar, para não cair na tendência interpretativa de explicar esta determinação pelos modelos mecanicistas que antes denunciara como comprometendo vários trabalhos pretensamente marxistas, o autor esclarece esta total determinação dos fenômenos supraestruturais pela infraestrutura, salientando o caráter estritamente dialético desta expansão e da correspondente expansão da esfera ideológica:

"Não há nada na composição do sentido que possa colocar-se acima da evolução, que seja independente do alargamento dialético do horizonte social. A sociedade em transformação alarga-se para integrar o ser em transformação. Nada pode permanecer estável nesse processo. É por isso que a significação, elemento abstrato igual a si mesmo, é absorvida pelo tema, e dilacerada por suas contradições vivas, para retornar enfim sob a forma de uma significação com uma estabilidade e uma identidade igualmente provisórias". (p. 122)

O tema como realidade viva, dinamiza-se no seio da sociedade em transformação. A significação reage devido ao seu caráter fundamentalmente estático e estratificante. Deste modo um fenômeno de rompimento interno do elemento convencional se estabelece nos momentos das revoluções sociais tendendo novamente a reencontrar as condições de uma nova estabilidade. Ao nível da enunciação, assim se realiza o processo da luta de classes e da efetivação de uma estrutura de poder. 
SILVEIRA, L.F.B. da. - A produção social da linguagem: uma leitura do texto de Mikhail Bakhtin (V.N. Volochinov), marxismo e filosofia da linguagem. Trans/Form/Ação, São Paulo, 4:15-39, 1981.

02.04. Um estudo de sintaxe: o discurso citado

\subsubsection{O Estatuto do Discurso Citado}

A terceira e última parte do livro, composta de quatro capítulos, desenvolve a aplicação da concepção de sintaxe assumida por BAKHTIN ao caso do discurso citado presente especialmente na obra literária. O fenômeno é conveniente para verificar e comprovar a validade da proposição teórica, por tratar-se de um caso limite entre uma construção de natureza gramatical e de um recurso estilístico que especialmente põe à prova as concepções interpretativas. (p. 142) Gramaticistas como TOBLER e KALEPKY; um eminente representante do objetivismo abstrato como BALLY e os partidários do subjetivismo idealista, LORCH e LERCH, seguidores das teorias de VOSSLER, abordaram o problema, procurando todos uma explicação do discurso indireto livre, e segundo o autor, falharam em seu intento.

Somente a explicação precisa e minuciosa do discurso e da enunciação como realizações completas do ato da fala, em sua realização escrita, como um fenômeno de natureza ideológica de cunho essencialmente social e capaz de formar a consciência individual pela determinação que mediatiza as condições sócio-econômicas do momento histórico que o produz, pode atingir o cerne do significado do discurso citado indireto - e em especial, em sua variante livre -, esclarecendo as condições das transformações estilísticas e da produção de formas gramaticais estáveis para sua expressão.

Os preconceitos da lingüística contemporânea, já denunciados anteriormente, afloram, ao ser analisado o discurso citado, sobretudo na variante livre do discurso indireto. Dominada pela forma monológica do discurso, decompondo-o ao nível das orações e analisando-as com categorias sintáticas redutíveis às formas elementares da morfologia e da fonética, esta concepção do fenômeno da linguagem mantém-se num nível abstrato, incapaz de recuperar a integridade da enunciação e, consequentemente, do discurso. (p. 125-127)

A interferência do discurso narrativo e do discurso citado recebe um tratamento extremamente simplista desprovido de qualquer adequação à natureza do fenômeno quando, por exemplo, A.M. PECHKOVSKY reduz tal construção à uma transposição do discurso direto ao indireto. (p. 143-144) Apresenta-se, em outras interpretações, como uma forma ilógica de construção gramatical em que, pela ausência de articulações explícitas (a conjunção "que" e os verbos introdutivos do discurso de outrem), só pode recuperar seu sentido extralingüisticamente. Tal é a posição do KALEPKY concluindo por uma ocultação do sujeito ao qual se atribuiu a fala (p. 163) ou a posição de BALLY ao acusar uma dissociação entre "forma lingüística" e "figura de pensamento", atribuindo a primeira ao autor e a segunda, reduzida a um pretenso domínio do sentido ao qual índice lingüístico algum corresponde, ao herói. (p. 164)

Os vosslerianos, por sua vez, tendendo constantemente a minimizar a função lógica e racional no fenômeno da expressão lingüística, encontram no recurso literário do discurso indireto livre um campo privilegiado para afirmar a instância subjetiva que se encontra na origem da fala.

Eugen LERCH e Gertraud LORCK voltam-se ao discurso indireto livre e procuram compreendê-lo no domínio da categoria do vivido, privilegiando-o entre os recursos literários. Para LORCK, as elipses gramaticais utilizadas pelo autor pelas quais autor, herói e narrador trocam suas falas ressaltam o papel ativo do imaginário, constituem a instância criadora da obra literária. É da imaginação do autor à imaginação do leitor que a mensagem se estabelece e a libertação da produção lite- 
SIL VEIRA, L.F.B. da. - A produção social da linguagem: uma leitura do texto de Mikhail Bakhtin (V.N. Volochinov), marxismo e fílosofia da linguagem. Trans/Form/Ação, São Paulo, 4:15-39, 1981.

rária dos rígidos esquemas lógicos impostos pela razão ao discurso é felizmente obtida pelo discurso indireto livre. (p. 168170) Nele encontra o analista um campo privilegiado para sua investigação: penetrar "no domínio da alma da língua". (p. 170)

LERCH dedicar-se-á a uma reconstituição histórica da expressão literária voltada à construção do discurso citado. Opondo sentimento à razão, encaminha sua análise até o século XVII francês quando as formas gramaticais se aperfeiçoando permitem, com os recursos da concordância dos tempos verbais, da omissão do verbo introdutório do discurso citado, do uso aperfeiçoado do imperfeito e da plena disposição na escolha dos pronomes, que o narrador tome posição autônoma não mais se dissolvendo na atividade mental do herói. LA FONTAINE em suas fábulas, trabalha com plena consciência o discurso indireto livre, harmonizando a análise abstrata e a impressão imediata, e expressando a simpatia profunda do autor com suas personagens. LA BRUYĖRE consegue obter efeitos satíricos, produzindo uma pseudoobjetividade que de fato serve para refratar ironicamente todas as suas representações.

No século XIX tal recurso chega à perfeição, quando FLAUBERT dardeja com seu olhar o que acha repugnante e odioso, mas explorando a ambivalência e a incoerência do discurso indireto livre, joga sobre o repugnante e o odioso sua sensibilidade e com eles se identifica. Revela assim a incoerência da própria atitude do autor.

Se a França aperfeiçou seus recursos lingüísticos para trabalhar o discurso indireto livre, nas outras línguas o processo se deu mais tardiamente. Em nosso século, porém, os outros idiomas nele chegaram, pela leitura, talvez, de autores como Zola. Thomas Mann recorre a este procedimen- to em seu Buddenbrook, aperfeiçoando-o na Montanha Mágica.

Não é mais a imaginação que responderá, para LERCH, pela instância expressiva da atividade literária mas a "sensibilidade simpatizante", a empatia (Einfühlung) para com a personagem, empatia suscitada no próprio leitor. (p. 171-173)

Baseado no caráter iminentemente sociológico e ideológico do fenômeno lingüístico e tendo por conseqüência a enunciação completa, dotada de tema e significação, como objeto elementar, a qual se. insere em sua produção em discursos dialogantes, BAKHTIN reconhece no fenômeno sintático do discurso citado a presença indissociável de dois aspectos estritamente articulados: o discurso citado é constituído por esquemas lingüísticos, tais como o discurso direto, o discurso indireto, o discurso indireto livre por suas modificações e variantes dessas modificações, elaboradas socialmente e interiorizadas pela consciência dos falantes para a transmissão das enunciações de outrem na medida em que as integra como de outrem, num contexto narrativo coerente e de natureza imediatamente monológica.

Daí propor o autor como problema a ser abordado nesse trabalho, dotar de uma orientação sociológica o fenômeno da transmissão da palavra de outrem, e através dele, traçar os caminhos do método sociológico em lingüística. Adverte, no entanto, que face ao restrito material analisado - a presença desses recursos em textos selecionados na literatura russa os resultados obtidos são limitados em sua extensividade, e que as generalizações históricas de maior porte que porventura ocorrerem na exposição, terão um caráter meramente provisório e hipotético. (p. 129)

O discurso citado é, genericamente, o discurso no discurso, a enunciação na enunciação, mas é também um discurso sobre o discurso, a enunciação sobre a enunciação. Daí a importância de analisar 
as articulações precisas entre o discurso narrativo e o discurso citado.

Quando a enunciação citada passa a constituir o tema do discurso narrativo, o tema autônomo - do discurso ora citado - torna-se o tema de um tema. (p. 130)

A enunciação do narrador, tendo integrado na sua composição uma outra enunciação, elabora regras sintáticas, estilísticas e composicionais para assimilá-la parcialmente, embora conservando, pelo menos numa forma rudimentar, a autonomia primitiva do discurso de outrem, sem o que ele não poderia ser completamente apreendido.

Esta elaboração, por mais ativa e criativa que seja da parte do autor do discurso narrativo, não se reduz quanto à origem, à mera subjetividade, como terá ocasião BAKHTIN de denunciar ao criticar não só a tendência geral dos vosslerianos mas a própria proposta de TOBLER de que, num certo momento, o falante resolvesse dispor, de modo diverso ao tradicional, a fala entre os falantes, para isto recorrendo a um jogo inaudito dos tempos e modos de verbo disponíveis na língua. (pg. 161-162). Desde a exposição inicial do estatuto do fenômeno estudado, o autor insiste que as formas usadas na citação do discurso refletem tendências básicas e constantes da recepção ativa do discurso de outrem. Tais tendências são geradas no seio social que escolhe e gramatiza apenas os elementos de apreensão ativa e apreciativa da enunciação de outrem que são socialmente pertinentes e constantes e que encontram seu fundamento na existência econômica de uma comunidade lingüística dada. (pg. 132).

Não cabe defender um reducionismo das formas da consciência às construções sintáticas, como não cabe defender a teoria especular em que as construções semióticas e literárias reproduzern passivamente as relações sociais, refratando-as, quando for o caso, por mera resistência material. As formas de apreensão ativa e apreciativa não se realizam diretamente sob as formas sintáticas, sob as formas, por exemplo, do discurso direto ou indireto. Estas formas de discurso, declara o autor, são esquemas padronizados para a citação do discurso de outrem. Tais esquemas, contudo, só podem ter surgido e tomado forma de acordo com as tendências dominantes de apreensão do discurso de outrem, tendo assumido uma forma e uma função na língua, quando então passam a exercer uma influência reguladora - estimulante ou inibidora - sobre o desenvolvimento das tendências da apreensão apreciativa, cujo campo de ação é definido por essas formas. (p. 133). Tratase, conseqüentemente, não de uma determinação mecânica que geraria um círculo vicioso ou mesmo uma tautologia, mas de um processo dialético entre o psicológico e o ideológico e entre o individual e o social.

“A palavra vai à palavra". A apreensão ativa do discurso exterior como atualização do fundo perceptivo do sujeito receptor se fará necessariamente pela mediação do discurso interior.

O processo de compreensão e de apreciação do discurso exterior far-se-á em dois planos inseparáveis mas que podem exercer, conforme o momento, dominância sobre o outro. Reelaborado ao nível do discurso interior, o discurso apreendido sofre o processo ao qual BAKHTIN denomina, em seqüência aos trabalhos de JAKOUBINSKY, de "comentário efetivo', Este processo 'constitui-se, ao menos parcialmente, no dizer do autor, no fundo perceptivo da palavra. Enquanto isto, prepara-se o receptor para assumir o papel de sujeito emissor, elaborando a réplica interior que pode vir a se exteriorizar. É com ela que se armará o contexto narrativo do discurso citado. (p. 133-134).

Estabelecida esta base conceitual, pode BAKHTIN encaminhar o trabalho para o objeto próximo de sua pesquisa. $\mathrm{Ci}$ - 
tando o próprio texto, assim este objeto se configura:..."o objeto verdadeiro da pesquisa deve ser justamente a interação dinâmica dessas duas dimensões, o discurso a transmitir e aquele que serve para transmiti-lo. Na verdade, eles só têm uma existência real, só se formam e vivem através dessa inter-relação, e não de maneira isolada. $\mathrm{O}$ discurso citado e o contexto de transmissão são somente os termos de uma inter-relação dinâmica. Essa dinâmica, por sua vez, reflete a dinâmica da inter-relação social dos indivíduos na comunicação ideológica verbal. (Trata-se naturalmente, de tendências essenciais e constantes dessa comunicação)'”. (p. 134).

Duas orientações compõem em seus fundamentos as relações entre o discurso narrativo e o discurso citado: o discurso direto e o discurso indireto.

O primeiro se constrói tendo em vista isolar o discurso de outrem e acentuar sua significação, evitando entremeá-la com interpretações da parte do autor do discurso narrativo. No quadro do dogmatismo racionalista aperfeiçoaram-se as formas e variantes que efetuam tal tipo de citação. Aproximando BAKHTIN suas considerações daquelas que WÖLFFLIN elaborara para distinguir a produção artística do Renascimento daquela que teve lugar no Barroco, na orientação que encaminha o discurso direto reconhece o "'estilo linear"': aquele em que, havendo completa homogeneidade estilística do texto, - falando o autor e a personagem a mesma linguagem -, no discurso construído como sendo do outro chega-se à máxima sobriedade e plasticidade. (p. 134-136)

O segundo, ao contrário, recorre a procedimentos construtivos que justamente permitam a infiltração de réplicas e comentários do autor no discurso de outrem. Trabalha com sutileza as citações de modo que se salientem os aspectos emotivos e avaliativos das enunciações. $\mathrm{O}$ con- texto narrativo dissolve a estrutura compacta e fechada do discurso citado. Realiza-se na literatura o "estilo pictórico" que WÖLFFLIN reconhecia no Barroco. Neste processo de interpenetração e de abertura para a introdução de funções mutuamente valorativas entre o discurso narrativo e o discurso citado, ora domina o colorido ef etivado pelo narrador no discurso citado; ora o discurso citado tende a dissolver o contexto narrativo. Aparece, então, o narrador no lugar do autor, e a narrativa passa a assumir a linguagem das personagens. Da primeira tendência, busca BAKHTIN exemplos na literatura francesa do Renascimento do final do século XVIII e em algumas obras do século XIX. Na literatura russa, GOGOL é o exemplo escolhido em sua tendência naturalista. Da segunda, o romance do final do século XIX é que melhor ilustra, aí se destacando DOSTOIEVSKI. (p. 136 138)

Tratando-se de orientações profundas da comunicação social, ao nível do discurso, é de fundamental importância considerar o fim procurado pelo contexto narrativo. O discurso literário tende a trabalhar com maior sutileza esta interrelação entre os discursos e a transmitir com mais matizes as transformações sofridas pela interorientação sócio-verbal entre autor e personagem. O discurso retórico é, de si mesmo, mais atento aos direitos de propriedade da palavra e à conseqüente autenticidade do discurso citado. Preocupa-se sobremodo com a hierarquia social de valores e tende a evitar réplicas e comentários a discursos provenientes de enunciadores localizados nos mais altos degraus da escala social.

Deste modo, pode-se entender por que formas mais flexíveis de citação indireta do discurso de outrem, onde o domínio do autor permite que este mais espontaneamente interfira com seus julgamentos de valor sobre o discurso citado, tenham despontado originariamente nos gêneros menores do classicismo, tais co- 
mo as fábulas de LA FONTAINE. (p. 138-139)

\subsubsection{2. - Esquemas e variantes da ci- tação do discurso de outrem.}

Fundamentando toda a análise no fenômeno concreto da enunciação, BAKHTIN considera o esquema de base do discurso, ou seja, o que o classifica em direto ou indireto, como uma organização abstrata que só se realiza sob a forma de variantes específicas. Essas variantes permitem a acumulação das mudanças das construções discursivas no curso da história, conduzindo à estabilização de nossos hábitos de orientação ativa em relação ao discurso de outrem, hábitos que se fixarão sob a forma de representações lingüísticas duráveis nos sistemas sintáticos.

A análise dessas variantes, presentes no discurso literário, permite a captação das tendências evolutivas da língua num momento histórico. (p. 141-142)

No discurso indireto, cuja significação é caracterizada pela transmissão analítica do discurso de outrem, estabelece-se a simultaneidade da análise da entoação do discurso citado e de sua transposição no contexto narrativo. (p. 144-145)

Tal discurso orienta-se em duas linhas principais, conforme queira salientar o conteúdo semântico preciso do discurso citado, ou a expressão do falante. Daí decorrem suas principais variantes, as quais se caracterizam ao nível de enunciações, por construções lingüísticas específicas. À primeira variante, BAKHTIN denomina discurso indireto analisador do conteúdo; à segunda, denomina discurso indireto analisador da expressão. (p. 146-147)

Enquanto a primeira retem-se no plano temático, transformando outros aspectos da construção em elementos integrantes do tema e do próprio contexto narrativo e guardando a distância que separa a narrativa do citado; a segunda variante integra na construção indireta a maneira de dizer do falante citado, podendo mesmo adotar recursos que, acentuando o "estranhamento do discurso narrativo à fala citada, dê ênfase a "colorações" que ressaltam os matizes da atitude do próprio autor, construindo assim uma imagem valorativa da personagem"'. (p. 147-150)

Se bem que o estudo de BAKHTIN tenha por meta a análise do discurso indireto livre, não deixa de levantar variantes do discurso direto. Tal levantamento, embora sumário, contribui para salientar a especificidade daquela variante que mais lhe interessa explicitar e para, hipoteticamente, esclarecer as condições que permitiram seu surgimento.

Das múltiplas concreções que pode assumir o discurso direto, destacam-se em duas etapas no texto de BAKHTIN, cinco classes de orientações e variantes.

O discurso pode ser introduzido de tal forma que seu tema seja antecipado por um discurso indireto. Seus temas básicos são previamente apresentados recebendo do autor o colorido que pretende ressaltar. A esta orientação, BAKHTIN denomina discurso direto preparado.

A preparação do falante citado pode ser marcada por uma caracterização tal que se torna dispensável a significação de fala para que o leitor reconheça a "coloração" de que ela é portadora. No teatro, por exemplo, a caracterização do palhaço predispõe a platéia à gargalhada antes mesmo que o ator pronuncie sua fala. Trata-se do discurso direto esvaziado.

A narrativa pode se disseminar na fala do herói. A narrativa irá se apresentar como saindo da consciência das personagens, o autor podendo dela se distanciar e por ela demonstrar ironia ou desprezo. O discurso da personagem principal se ocultará, e as palavras da narrativa passarão a pertencer simultaneamente, do ponto de vista da expressividade, a dois contextos que se entrecruzam: o do autor-narrador 
que imprime ironia à fala da personagem e o da personagem-objeto desta valoração, cuja fala, nada de irônica. Tem-se aí uma variante especial do discurso direto. (p. 151-155)

Outras duas variantes serão apresentadas: a do discurso direto retórico e a do discurso indireto substituído. Nelas, propõe BAKHTIN, encontraria o discurso indireto livre, condição para seu surgimento.

Localizando-se na fronteira do discurso narrativo e do discurso citado, o discurso direto retórico constitui-se pela intervenção do autor na cena narrada como porta-voz do herói. Atravessa assim o discurso citado na forma direta com uma fala que tem por finalidade provocar a persuasão do leitor, ou da audiência, à fala do herói e se constitui em pergunta ou exclamação que conota a gravidade da atitude narrada e da fala citada. O autor pergunta, por exemplo, em nome do herói, numa situação que exige decisão: "o que fazer?',

Pelo discurso direto substituído, estabelece-se um paralelismo de entoação. Trata-se de um discurso que a personagem deveria pronunciar e do qual o autor se encarrega. O discurso indireto livre conhece também um processo de superposição de discursos, mas no caso aqui tratado, e que exatamente se justifica como discurso direto, não há interferência do discurso narrativo sobre o discurso citado.

No discurso indireto livre convergem dois discursos diferentemente orientados e o discurso citado apresenta suficiente flexibilidade para resistir por trás da transmissão valorativa ef etuada pelo autor (p. 155-158).

\subsubsection{3. -- O discurso indireto livre}

Reconhecendo no discurso indireto livre uma tendência nova e positiva na apreensão ativa da enunciação de outrem e uma orientação particular da interação do discurso narrativo e do discurso citado, depois de expor as diversas interpretações lingüísticas e psicológicas que dele foram dadas e de discuti-las, BAKHTIN procura explicá-lo coerentemente com sua concepção do fenômeno lingüístico e nele verificar a oportunidade e adequação desta concepção.

Se foi a corrente vossleriana do "subjetivismo idealista" que mais se dedicou ao estudo do fenômeno, nele reconhecendo notável expressão da individualidade, é contra seus pressupostos que o pensador russo argumentará, retomando, em parte, as críticas que antes fizera à concepção subjetivista e individualista do fenômeno da expressão lingüística, mas contribuindo com alguns esclarecimentos de não pouco interesse.

A realidade subjetiva do falante não existe fora de sua materialização objetiva na língua. Fora da expressão lingüística, a personalidade não existe nem para si nem para os outros. A personalidade interior subjetiva, constituindo-se numa forma de representação de relações sociais, é um ideologema. Não pode, pois, constituir-se numa base consistente para, a partir dela, se estabelecer explicações de tipo causal.

Mais ainda, seria inverter os termos da relação explicativa, partir da subjetividade para esclarecer o fenômeno lingüístico e comunicativo. O ideologema permanece informe e instável quando não for determinado graças aos produtos mais estáveis e elaborados da criação ideológica.

É a língua que ilumina a personalidade interior e a consciência; que as cria, diferencia e aprofunda.

A personalidade é, do ponto de vista de seu conteúdo interior, o tema da língua e esse tema desenvolve-se e varia no quadro das estruturas lingüísticas mais estáveis. Deste modo pode inferir BAKHTIN que não é a palavra que constitui a expressão da personalidade interior, mas, ao 
SILVEIRA, L.F.B. da. - A produção social da linguagem: uma leitura do texto de Mikhail Bakhtin (V.N. Volochinov), marxismo e filosofia da linguagem. Trans/Form/Ação, São Paulo, 4:15-39, 1981.

contrário, esta última constitui uma palavra contida e interiorizada. A palavra é a expressão da comunicação social, da interação social de personalidades definidas, de produtores. E as condições materiais da socialização determinam a orientação temática e constitutiva da personalidade interior numa época e num meio determinado (p. 174).

A evolução da consciência individual depende da evolução da língua, consideradas as estruturas gramaticais como concretamente ideológicas. A evolução da língua, por sua vez, é determinada pela evolução da comunicação social e de suas bases materiais.

A evolução da língua determina os destinos da enunciação individual num determinado momento, seu grau de resistência a influências, o grau de diferenciação dos seus diversos aspectos e a natureza de sua individualização semânticoverbal. Esta expressão da individualidade se faz primeiramente nas instâncias mais estáveis da língua, tanto em seus esquemas, quanto em suas variantes. A personalidade do falante aparece como uma construção dotada de estabilidade à qual sempre se une um conteúdo temático particular.

Se o sujeito é o agente da enunciação, ele acontece dentro das possibilidades concretas que a língua, como recurso de comunicação social, lhe oferece e a própria enunciação reage sobre o falante na configuração de sua personalidade.

A apreciação da formação do discurso indireto livre não pode, pois, pautar-se numa possível evolução da imaginação subjetiva e de sua possível exaustão, como pretende LORCK reconhecer na burguesia francesa autora dos textos literários e que o leva a esperar que uma renovação se produzirá no momento em que o proletariado começar a se expressar.

No fenômeno lingüístico objetivo do discurso indireto livre, escreve BAKHTIN (p. 177), não temos a combinação de empatia e distanciamento dentro dos limites da alma individual. Trata-se, outrossim, de uma inter-relação específica entre o discurso narrativo e o discurso citado, de uma forma própria de apreensão ativa do discurso de outrem na qual combinam-se as entoações da personagem, como empatia, e das entoações do autor, como distanciamento, dentro dos limites de uma mesma e única construção lingüística. A construção objetiva do discurso não é um instrumento amorfo dependente da subjetividade que se exprime. É necessário levar em conta o julgamento de valor inerente e toda palavra viva, revelado pela acentuação e pela entoação expressiva da enunciação, donde decorre o sentido do discurso.

É com esta peculiar concepção de sintaxe que pode BAKHTIN abordar o discurso indireto livre sem precisar reconhecer sua especificidade numa franja de irracionalidade a que tanto os vosslerianos quanto os gramaticistas recorriam. Trabalhando com o conceito de enunciação como elemento concreto da fala, o qual compreende um tema não redutível à significação mas integrado igualmente por elementos de valoração, pode o autor explicar sua especificidade pela identificação da palavra citada, graças às entoações e acentuações próprias do herói e à orientação apreciativa do discurso. Aí se percebe que os acentos e as entoações do autor estão sendo interrompidos pelos julgamentos de valor de outra pessoa. Este atravessar de acentuações o caracteriza como discurso indireto, como discurso analítico, e o diferencia radicalmente do discurso direto substituído, no qual nenhum acento novo aparece em relação ao contexto narrativo (p. 177).

Seu caráter indireto, especialmente complexo, impede a encenação absoluta. Somente a adaptação da prosa à leitura silenciosa - o que é de se notar como um fenômeno peculiar da civilização moderna e do papel do indivíduo dela decorren- 
te - tornou possível a superposição dos planos e a complexidade intransmissível oralmente de suas estruturas entoativas (p. 178).

\subsection{5. - As dimensões sociológicas da análise do discurso indireto livre.}

À guisa de conclusão, sem para ela dedicar um capítulo à parte, BAKHTIN projeta sobre as relações sociais os resultados obtidos pela análise do discurso indireto livre.

Retomando o estatuto específico da palavra como produção social, pode-se resumir deste modo o primeiro momento das conclusões do texto: a palavra, como fenômeno ideológico por excelência, está em constante evolução e reflete a seu modo, mas fielmente, todas as mudanças e alterações sociais que a determinam ( $p$. 180).

Se a palavra pode ser investigada em sua evolução semântica, ou na trama da história do conhecimento, - da evolução da verdade - ou na história da literatura, - na evolução da verdade na arte - , pode também ser abordada no estudo da língua como material ideológico, como meio onde se reflete ideologicamente a existência. Tais estudos levantarão o processo de reflexão e da refração da natureza e da história na evolução da palavra.

Pode no entanto, o estudo da palavra voltar-se para os fenômenos que se passam na própria palavra, quer elaborando uma história da filosofia da palavra, quer, no que BAKHTIN denomina, história da palavra na palavra, onde reconhece ter realizado seu trabalho. Trabalha, com ef eito, a palavra na palavra e a palavra sobre a palavra, ao analisar os esquemas básicos e as variantes da citação do discurso de outrem.

Se dentre as formas concretas de citação, voltou-se especialmente ao discurso indireto livre, dele tirará agora conse- qüências elucidativas das relações sociais. que permitiram seu surgimentọ e evolução.

Ao lado de outras variantes expressivas do discurso direto e indireto, o discurso indireto livre implica em desenvolvimentos importantes das línguas européias contemporâneas e denuncia uma... "reviravolta importante no destino social da enunciação'”. (p.181)

Colorindo e atravessando o discurso citado e imiscuindo o posicionamento do autor na trama das personagens, o discurso indireto livre e as variantes que lhe são contemporâneas e que igualmente compartilham do mesmo "estilo pictórico" extremado de discurso, somente se impuseram na literatura ocidental devido a um processo de "subjetivação prof unda e generalizada da palavra - enunciação ideológica"'. (p.181)

O núcleo semântico da palavra não mais impera na enunciação e, com ele, o papel hegemônico da asserção. A palavra é percebida, salvo no caso dos contextos científicos, como a expressão de um estado subjetivo fortuito. Mesmo as ciências humanas parecem admitir o domínio da opinião e suas proposições se impõem na medida em que se apresentam como a melhor solução possível de um problema. A enunciação apresenta-se instável e incerta; ou diríamos, provável e provisória.

$\mathrm{Na}$ ficção, e daí a importância e o desenvolvimento crescente do discurso indireto livre, "toda a atividade verbal consiste em distribuir a palavra de outrem e a palavra que parece ser a de outrem". (p.181)

A depreciação do núcleo semântico dá origem não só às formas indiretas de citação em que a carga valorativa e idiossincrática do discurso do autor predomina sobre "o que" é dito, como dá lugar a um processo presente, tanto na poética quanto nas ciências da linguagem, de reificar a palavra. O formalismo predomina na so- 
ciedade burguesa ocidental, assim como no contexto do mundo soviético.

A isençäo que mantinha BAKHTIN no estudo do fenômeno lingüístico, procurando abrangê-lo em sua integridade mas sem tomar posição sobre a produção social da linguagem, é finalmente prejudicada no final do texto. Emitindo um juízo de valor sobre esta tendência crescente de realização da função temática, propõe o autor que se promova uma renovação da palavra ideológica. Cabe, a seu ver, uma recuperação da palavra com seu tema intacto, penetrada por uma apreciação social segura e categórica, que realmente signifique e seja responsável por aquilo que diz. É difícil dizer se tal proposta corresponde a uma posição própria do autor, disposto a interferir no processo da produção discursiva literária e científica, ou se aí não se encontra uma estratégia de adequação a uma política que iniciaria um controle do Estado na produção ideológica; política que iria inaugurar o período lamentável e dificilmente superável do "realismo socialista".

\section{3. $O$ que dizer de "Marxismo e Filosofia da Linguagem"}

Esta leitura, que chega a seu término, não pretende contrapor à proposta de BAKHTIN outro modo de tratar o fenômeno da produção lingüística. $\mathrm{O}$ mérito do livro é indiscutível, quer pela seriedade como aborda o tema, quer pela originalidade com que o desenvolve. Recusando a situação simplista de acompanhar as análises anteriormente realizadas ou de meramente aplicar ao fenômeno da linguagem um modelo esquemático deduzido das teses do materialismo histórico sobre a pro- dução supra estrutural, procura ir ao fundo do processo de produção simbólica, desenvolvê-lo teoricamente e investigá-lo num caso elucidativo tal como é o do discurso citado. Enfrenta resolutamente as teorias mais importantes, apresenta-as com respeito e rigor e as critica com admirável lucidez. Trabalha com cuidado o fenômeno à luz do materialismo histórico sem cair nas falhas freqüentes de um mecanicismo.

Se a escolha da produção lingüística como objeto suficiente para a compreensão da produção social no domínio semiótico pode ser criticada, e se a teorização do signo que procura respeitar a integridade do fenômeno apresenta alguma obscuridade e insegurança, isto não retira o valor do texto. A eleição do texto literário como lugar de verificação de um fenômeno que atravessa todo o domínio da produção semiótica e cuja análise, mesmo estabelecendo restrição quanto ao valor da inferência e da generalização, pretende elucidar um fenômeno que recobre as diversas dimensões das relações sociais ao nível da representação ideológica, também fica sujeito a alguma suspeição.*

Tomar a enunciação completa como objeto central da lingüística e assumi-la, não como entidade abstrata ou decomponível e articulável num quadro de posições e oposições; considerá-la como um todo complexo, integrada por componentes gramaticais responsáveis pela significação e por componentes de valoração e entoação e não permitir isolar somente um deles para elaborar a teoria lingüística; trabalhar o fenômeno, por conseqüência, ao nível do tema; recuperar no estudo das regras de composição da sintaxe toda esta complexidade e projetar a enunciação

* O Artigo de nossa autoria: A Produção do Signo numa Estrutura Social Antagônica. Trans/Form/Ação, São Paulo, 3: $81-90,1980$, dedica-se em grande parte ao desenvolvimento dessas criticas, sobretudo no que concerne a redução do signo ao domínio do simbólico e a superposição da superestrutura (de caráter ideológico) à infra-estrutura (constituida pelas relações materiais de produção). A proposta veiculada pelo artigo é encaminhar a análise das formas de representação da consciência através de teorias semióticas que incorporem a seus objetos a classe geral dos signos e não somente os signos convencionais e que, conseqüentemente, estendam a análise da produção semiótica até o momento originário do embate material das forças produtivas. Para o conhecimento e avaliação dessas criticas remetemos o leltor ao ref erido artigo. 
no conjunto mais complexo, e mais concreto, do discurso; elucidar os discursos como formas de natureza essencialmente dialógica, parece-nos a contribuição central de BAKHTIN para o estudo da linguagem, capaz de redimi-lo das conseqüências de um fracionamento incapaz de recuperar no objeto de investigação, a integridade do fenômeno. Deve-se ainda reconhecer que a enunciação como fenômeno íntegro, permite a recuperação integral da análise morfológica e fonética nos limites precisos de seus objetos próprios. Também a separação, freqüentemente denunciada, entre o signo lingüístico neutro e integralmente articulado a partir de componentes elementares perfeitamente decomponíveis e classificáveis e outros, irredutíveis a uma sistematização discreta, - tais como os signos figurativos, kinésicos e proxêmicos analógicos em sua forma e imediatamente significativos - separação mais acentuada do que dissimulada num pretenso reducionismo de todos os signos ao modo de se estruturar do signo lingüístico, é corrigida na base pela proposta de BAKHTIN. Todo o signo é temático e essencialmente ideológico, conseqüentemente, todo o signo é fundamentalmente enunciativo, e diríamos, analógico. Se tomarmos a enunciação e o discurso como as instâncias fundamentais para a análise mesmo de natureza sintática, o signo lingüístico não mais se isolará como uma classe absolutamente estranha no universo total das semioses: guarda evidentemente seus traços específicos, apresentando-se, porém, como uma realização particular de um fenômeno geral. A possibilidade de sistematizar discretamente certos aspectos do signo lingüístico não mais dá conta de sua integridade e, conseqüentemente, não mais o discrimina essencialmente das outras classes de signos. $\mathrm{O}$ modo de trabalhar o signo lingüístico proposto por BAKHTIN supera igualmente a necessidade de desconsiderar, ao nível da ciência, aqueles aspectos essenciais da comunicação verbal que, no en- tanto, eram classificados como paralingüísticos.

A natureza intrinsecamente social e ideológica do signo lingüístico, - assim como de todo fenômeno semiótico - e as relações que com ele estabelece a instância da representação da consciência, é, sem dúvida, a tese mais claramente defendida por BAKHTIN. De seu desdobramento, constrói-se toda a teoria. É ao nível da polêmica que o texto se confronta com as outras correntes que estudam o fenômeno da linguagem. Por tratar-se de uma questão primeira de natureza críticofilosófica, divide definitivamente as posições. Aceita a posição, as divergências se localizarão ao nível dos desdobramentos para melhor adequação ao fenômeno e para melhor clarificação dos conceitos. Basicamente a posição de BAKHTIN é bem apresentada e se imperfeições existem, elas decorrem de seu caráter originário às vezes um pouco tosco em sua formulação. Note-se, somente como um exemplo, a exposição da instância interior da "apresentação ativa", pouco analisa$\mathrm{da}$, à qual BAKHTIN denomina "fundo perceptivo”. Que tal instância se efetue no interior da linguagem como produto social e integre ao nível subjetivo o conjunto das relações sociais de natureza simbólica, está em coerência com seus pressupostos e, a partir deles, deve ser aceita, mas o processo desta apreensão suporia uma análise mais clara e minuciosa. $\mathrm{O}$ trabalho do inconsciente, que certamente não é desconhecido do autor que antes já dedicara um estudo à obra de FREUD, não é explicitado no livro que lemos. A articulação concreta, reconhecida pelo autor como o "comentário efetivo" de JAKOUBINSKI, que fornece condições para a efetivação da "réplica interior", implica certamente um conjunto de operações bastante complexas, não somente ao nível específico, - objeto da psicologia - mas mesmo ao nível de uma abordagem filosófica, onde conhecimento, decisão e linguagem - sobretudo como 
constituição do discurso interior - se relacionam. Mesmo mantendo-se no nível hipotético da construção teórica, o único, certamente, que é possível de se manter para a explicação de operações intramentais, o autor deveria ter desenvolvido melhor sua análise.

A exclusão drástica da função imaginativa, - ou melhor, função ao nível do imaginário, lugar concreto em que o acúmulo de conhecimentos e aptidões passadas já adquiridas se conjuga com a fala de outrem para a produção do discurso interior e da conseqüente réplica exteriorizada -, que contrapõe BAKHTIN à proposta de LORCK (p. 176) quando este esperava, idealisticamente, que o proletariado pudesse vir a assumir um papel renovador na produção dos discursos literários, parece decorrer deste tratamento demasiadamente sumário da produção do discurso interior.

É certo que a tese de LORCK sobre a imaginação peca por uma hipertrofia do subjetivo, e sob este aspecto devia ser criticada por BAKHTIN. Mas o imaginário com uma função ativa de estabelecer as relações de causação e de significação dos signos, organizando-os para uma nova enunciação, não poderia ser excluído sem maior cuidado, caso não se quisesse cair no erro da teoria especular que caracterizara o "mecanicismo" pretensamente marxista e mesmo uma certa variante do behaviorismo.

Falhas desta ordem despontam aqui ou lá no texto de BAKHTIN, mas um caminho fica aberto a partir de "Marxismo e Filosofia da Linguagem", para séries extremamente fecundas de análise do fenômeno social da produção da linguagem e da literatura.

Acompanhando o texto proximamente em suas articulações, tivemos em vista facilitar a leitura da obra. Explicitamos os elementos fundamentais da argumentação, sobretudo procurando reconstituir uma possível unidade do texto. Tomamos a liberdade de recontá-lo, agrupando as críticas às posições opostas à do autor de modo a sistematizar melhor sua proposta teórica e os resultados de sua análise. Numa tentativa de ressaltar esta proposta, deixamos de comentar o trabalho de leitura dos textos literários ao qual o autor se dedica sobretudo ao discutir os diversos esquemas e variantes de discuirsos citados.

Temos finalmente a reconhecer a oportunidade da tradução para o português desta obra, assim como a seriedade como foi feita. Se a tradução revela cuidado e critério, infelizmente não se pode dizer o mesmo do serviço de impressão que, invertendo freqüentemente linhas do texto, dificulta profundamente sua leitura. Algumas dessas falhas conseguimos corrigir através da leitura atenta da obra, outras não conseguimos recolocar em seu devido lugar, impossibilitando-nos recuperar a integridade do texto.

Tais defeitos devem ser denunciados a fim de incentivar os responsáveis pelas publicações feitas no Brasil a melhorar sua qualidade.

Esperamos que a extensão demasiada desta leitura não desanime o leitor a tomar o texto de BAKHTIN e lê-lo com espírito crítico e isenção face a nossa análise e interpretação. O confronto de interpretação contribui para o desenvolvimento de um trabalho de intelecção do discurso do autor, e em se tratando de uma obra que abre um espaço para investigações futuras, tal confronto é ocasião para o aperfeiçoamento da pesquisa daqueles que se dedicam a esta área da produção social. 
SILVEIRA, L.F.B. da - The social production of language: a reading of Mikhail Bakhtin (V.N. Volochinov) marxism and philosophy of language. Trans/Form/Ação, São Paulo, 4:15-39, 1981.

ABSTRACT: Faced with the problem of lying foundations for the semiotic production inside the capitalistic social and economic formation and even inside the first phase of the establishment of socialim, Bakhtin, or his disciple Volochinov, discusses the propositions of Linguistics along the line of the saussurian tradition and the propositions of the vosslerian individualistic subjectivism; he avoids the pretendedly marxist mechanicism and proposes establishing the social and ideologic instance of the formation of discourse. After formulating the general principles of the social production of signs, Bakhtin analyses the indirect discourses which have been gradually elaborated in the French bourgeois literature since the 18th century.

KEY-WORDS: Language; sign; theme; utterance; valuation; intonation; direct discourse; indirect discourse; free indirect discourse; inf rastructure; superstructure; ideology. 